\title{
EFECT OF PRE-COOLING AND COLD STORAGE ON QUALITY AND QUANTITY OF SOME MEDICAL PLANTS
}

\author{
Yossry B. Abd Elhay*
}

\begin{abstract}
The object of the present study was to investigate the effect of pre-cooling and cold storage process on safe storage period, fresh weight loss, chlorophyll $a$ and $b$, and volatile oil percentage and effect the optimum parameters on volatile oil components for Rosemary (Rosmarinus officinalis L.), and Spearmint (Menthaviridis Linn.) herbs. The precooling process was done using cool medium at $5^{\circ} \mathrm{C}$, and then the herbs were stored under three levels of storing temperatures of $\left(2,4\right.$ and $\left.6{ }^{\circ} \mathrm{C}\right)$ and relative humidity $(\mathrm{RH})$ of $98 \%$. The obtained results from the experiment indicated that for both herbs under study should be precooled at $5{ }^{\circ} \mathrm{C}$ and stored at $2{ }^{\circ} \mathrm{C}$ and $98 \%(\boldsymbol{R H})$ to increase storage period, quantity and quality of oil, and to decrease the fresh weight loss for fresh consumption or marketing. Storage period at these conditions were 28 and 24 days, fresh weight loss were 1.29 and 9.98(g)/ $100 \mathrm{~g}$ fresh herbs, and percentage of the extracted volatile oil were 0.371 and $0.281 \%$ for Rosemary and Spearmint herbs, respectively. Also at these conditions the quantity of volatile oil components was greater than the quantity of volatile oil if no pre-cooling was used. There was no difference found between pre-cooled and non-pre-cooled herbs and between the three storage temperatures of 2,4 , and $6^{\circ} \mathrm{C}$ on chlorophyll ' $a$ ' and ' $b$ ' content for all plants under study.
\end{abstract}

Keywords: pre-cooling-cold storage-rosemary-spearmint-volatile oil.

\section{INTRODUCTION}

$\mathrm{P}$ re-cooling by removing field heat from freshly harvested herbs and or fruits reduces microbial activity and gave the best longest storage period, fresh consumption or marketing after harvesting and good marketing quality.

\footnotetext{
* Assist. Prof., Agric. Eng. Dept., Fac. of Agric., Cairo Univ., Giza, Egypt.
} 
Furthermore, this also decreases the ripening rate, diminishes water loss and decay, and thus, helps preserving quality and prolongs shelf life of the herbs. Also pre-cooling is the first step in good temperature management. The field heat of a freshly harvested crop-heat the product holds from the sun and ambient temperature-is usually high, and should be removed as quickly as possible before shipping, processing and storage. Pre-cooling is generally a separate operation requiring special equipment and or rooms to maximize the shelf life of the fresh agricultural products including the medicinal and aromatic herbs to be on demand whenever required for a logic period.

In Egypt, aromatic plants production must be extend because of our suitable environmental conditions including mild climate and abundance in soil types and especially the reclaimed ones.

Rosemary (Rosmarinus officinalis L.) is one of the most important medicinal and aromatic perennial plants. It is used externally as parasiticide, cicatrisant, for muscular pains and rheumatism, dandruff and eczema. It promotes hair growth and stimulates scalp. Internally it is used for asthma, bronchitis. Whooping cough, to stimulate poor circulation, it is employed for palpitation, debility, headache, neuralgia, rental fatigue, nervous exhaustion and stress-related disorders, dyspepsia, flatulence, hepatic disorders, hyper cholesterol aemia and jaundice (Lawless, 1992). Its oil is extensively used in soap, detergents, cosmetics, house-hold sprays and perfumes especially colognes. Also extensively used in most major food categories, especially meat products and drinks. Serves as a natural antioxidant (Lawless, 1992). Menthaviridis Linncommonly called Spearmint. It is a herbaceous perennial, with a pungent smell. The herb is considered as stimulant, carminative, antispasmodic, stomachic and diuretic, and it is also used for gastric pain, rheumatism, toothache, muscle pain and mouth wash (Ambasta, 1986) and it is generally given for fever and bronchitis and its decoction is used as lotion in aphthae (Mhaskar et al., 2000). Mentha extract has been found to have anti-oxidant and anti-peroxidant properties due to the presence of eugenol, caffeic acid, rosmarinic acid and $\alpha$-tocopherol and it could enhance error-free repair for DNA damage and hence could be 
anti-mutagenic (Vokovic-Gacis and Simic, 1993). Aqueous extract provides protection against radiation induced chromosomal damage in bone marrow of mice by decreasing serum acid phosphatase and increasing serum alkaline phosphatase (Samarth and Kumar, 2003). CAGMC (2002) reported that Peppermint is one of the major aromatic plants in Egypt, one fadden producing about 15-20 ton fresh herbs and they give about $25-30 \mathrm{~kg}$ volatile oil .Watada, (1986) mentioned that yellowing of leafy vegetables, such as spinach and parsley occurs with degradation of chlorophyll. Temperature is the most influential factor in rate of degradation, but the atmosphere could have effect. Yamauchi and Watada (1991) found that degradation of chlorophyll appeared to be regulated through the peroxidase-hydrogen peroxide pathway, which opens the prophyrin ring, thus resulting in a colosless compound. This conclusion was arrived at from the analysis of chlorophylls and their metabolites by HPLC, chlorophyll decreased at $25{ }^{\circ} \mathrm{C}$ but not at $1{ }^{\circ} \mathrm{C}$. Cantwell and Reid (1993) found that quality characteristics of fresh coriander herbs include a fresh appearance, uniformity of leaf size, form and colour, characteristics of aroma and flavour; and a lack of defects, such as decay or yellowing which are best maintained by lowtemperature and high-humidity storage. Gillies and Tovionen (1995) studied the effect of cooling method and packaging with perforated film on broccoli (Brassica oleracea L.) quality during $2{ }^{\circ} \mathrm{C}$ storage. Hydrocooling was the most rapid cooling method and resulted in the lowest vapour pressure deficits between the broccoli and the surrounding air. Broccoli that was hydro-cooled and then over wrapped with perforated film lost less weight, was firmest, and retained colour better. Gomez et al. (1999) assessed weight loss and quality (appearance, aroma and colour) in fresh coriander ( 8 g packages) stored at 4,10 and $25{ }^{\circ} \mathrm{C}$ for 2 , 4,6 and 8 days. They found that quality parameters decreased as storage temperature increased and storage at $4{ }^{\circ} \mathrm{C}$ is recommended for preserving quality for one week, although weight loss after 8 days at $4{ }^{\circ} \mathrm{C}$ was approximately $50 \%$.

Kuen Woo et al. (2000) investigated the MA response of fresh Cymbopogon citrates depending upon film packing and storage temperatures. Fresh weight loss was significantly lower at 5 and $0^{\circ} \mathrm{C}$ than 
at higher temperatures. Rapid accumulation of $\mathrm{Co}_{2}$ was observed at high storage temperatures. The ethylene content during the whole storage period was higher at $0^{\circ} \mathrm{C}$ than $5{ }^{\circ} \mathrm{C}$, but concentration remained below 1 ppm and did not adversely affect quality. Rouraet al. (2000) stored fresh spinach beet leaves at 4 or $18{ }^{\circ} \mathrm{C}$ and 43,86 and $98 \%$ relative humidity $(\mathrm{RH})$ as leaf quality was unacceptable after 3 days of storage at $18{ }^{\circ} \mathrm{C}$ regardless of $\mathrm{RH}$ level, leaves held at $4{ }^{\circ} \mathrm{C}$ and $43 \% \mathrm{RH}$ were unacceptable after 4 days storage due to dehydration. Alvares et al (2007) on parsley indicated that, hydro-cooling procedure reduced the loss of fresh weight from the leaves in the first 12 hours of storage and maintained the relative water content (RWC) at a high level even after seven days of storage at $5{ }^{\circ} \mathrm{C}$. Visual wilting of leaves was observed when approximately $10 \%$ of the initial fresh weight was lost, which was achieved 30 hours after harvest for the control and 42 hours for the precooled bunches.

This research aims to study the optimum parameters of pre-cooling and cold storage and its effect on the safe storage period, fresh weight loss, chlorophyll $\mathrm{a}$ and $\mathrm{b}$, and volatile oil percentage and its components for two different herbs Spearmint (Menthaviridis Linn.), and Rosemary (Rosmarinus officinalis L.) at pre-cooled of $5^{\circ} \mathrm{C}$ cooling temperature before storage into cold storage unit at different levels of storing temperature $\left(2,4\right.$ and $\left.6{ }^{\circ} \mathrm{C}\right)$ and constant relative humidity of $98 \%$.

\section{MATERIAL AND METHODS}

In the present investigation the pre-cooling and cold storage process were used for transport and storage medical plants of Spearmint (Menthaviridis Linn.), and Rosemary (Rosmarinus officinalis L.) to investigate the effect of pre-cooling and cold storage process on the safe storage period, fresh weight loss, chlorophyll $\mathrm{a}$ and $\mathrm{b}$, and volatile oil percentage and its components at pre- cooled of $5^{\circ} \mathrm{C}$ cooling temperature before storage into cold storage unit at different levels of storing temperature $\left(2,4\right.$ and $\left.6{ }^{\circ} \mathrm{C}\right)$ and constant relative humidity of $98 \%$. The samples of plants were taken from the privet farm of Medicinal and Aromatic plants, in 2015. The properties of plants were analysed at the 
laboratory of the Medicinal and Aromatic plants Research Department, Horticulture Research Institute. The oil percentage and its components were distillate from the plant leaves in the laboratory of the same department.

\section{Herbs used in this investigation:}

For Rosemary (Rosmarinus officinalis L.) plants the terminal steam cutting of (15 cm length) and the well rooted vegetative parts (runners) of equal size 8-10 cm length, with 5-8 leaves were used. While the areal stem terminal parts of Spearmint(Menthaviridis Linn.) $12-15 \mathrm{~cm}$ in length with 10-12 leaves were used (approximately 50g for package at foam).

\section{Measurements:}

The following data were recorded:

- Safe storage period (days):

The storage period in which the fresh herb of the pre-cooled and non-pre cooled remained in good quality till the beginning of deterioration was measured.

- Fresh weight loss (g):

The difference between weights of sample before and after storage was determined by digital balance with accuracy of $0.1 \mathrm{~g}$.

- Photosynthetic pigments determination of the fresh leaves:

Chlorophyll $\mathrm{a}$ and $\mathrm{b}$ as well as carotenoids contents were determined in fresh leaves (mg/g) according to the procedure of Saric et al. (1967).

- Volatile oil and its components:

Distillation of the volatile oil was preceded as described in the British Pharmacopoeia (1963). The volatile oil obtained from the herbs was analysed using Dschrom 6200 Gas Chromatograph equipped with a flame ionization detector for separation of volatile oil constituents.

- Plants temperature:

The digital universal temperature meter with copper-constantan thermocouple was used for measuring the temperature change of plants during the pre-cooling process.

\section{Experimental treatment and producer:}

The freshly harvested herbs were divided into two parts one of them was kept without pre-cooling and the other one was subjected to cooling with 
pre-cooling at $5 \pm 1.0{ }^{\circ} \mathrm{C}$ before storing at storage temperature of 2,4 and $6{ }^{\circ} \mathrm{C}$ and $98 \%$ relative humidity (R.H.). The storage done in three refrigerators (Labconco, Model No. 77555, Labconco Corporation, Kansas City, US) at the Horticulture Research Institute, A R C, Dokki, Giza, Egypt.

Pre-cooling treatment was done by using ice box where the harvested herbs were filled in polyethylene bags $(100 \mathrm{~g} / \mathrm{bag})$ and preciously tighted to avoid water leakage into the bags, then they were placed in the box immediately after harvesting to remove field heat before storage. The box was filled with ice cubs and cold water as a cooling medium. The temperature of the ice-water mixture was adjusted by using a digital temperature monitor as an indicator for adding ice cubes to the mixture to keep the required level of temperature all over the cooling period. Three copper constantan thermocouples were fixed at the centre of the tested samples to measure the temperature changes of the plants during the cooling process at 5 minutes internal. The fresh herbs of the two treatments (without pre-cooling and with pre-cooling) were cleared from damaged leaves for obtaining a uniform samples and packed in foam dishes $(24 \times 18 \times 3 \mathrm{~cm})$ covered with cured polyethylene shrink film (each sample weight was $100 \mathrm{~g}$ in the package). The samples were stored at storage temperature of 2,4 and $6{ }^{\circ} \mathrm{C}$ and $98 \% \mathrm{RH}$ in the refrigerator at the Horticulture Research Institute, (A. R. C) Dokki, Giza, Egypt. The relative humidity was kept at the previously mentioned level using a humidistat and a water misting apparatus.

\section{RESULTS AND DISCUSSION}

Effect pre-cooling process and storage temperatures on weight loss:

Fig. 1 shows the effect of pre-cooling process and storage temperatures on fresh weight loss ( $\mathrm{g}$ ) of Rosemary and Spearmint .It is also clear that from fig. 1 there is high effect of pre-cooling process and storage temperatures on fresh weight loss $(\mathrm{g})$. By using pre-cooling and decreasing storage temperature from 6,4 and $2^{\circ} \mathrm{C}$, the fresh weight loss (g) of Rosemary and Spearmint decreased in general. It could be found that the non- pre-cooled treatments gave the highest fresh weight loss 
when compared with the pre-cooled treatments in all cuts for Rosemary and Spearmint. Also the fresh weight loss increased by increasing the storage temperatures from 2 to $6^{\circ} \mathrm{C}$.It is due to decreasing in degradable tissues and the higher respiration rate of the stored herbs.

By increasing storage temperatures from 2 to $6^{\circ} \mathrm{C}$., the Fresh weight loss increased from 3.25 to $4.67 \%$ and from 15.1 to $16.34(\mathrm{~g}) / 100 \mathrm{~g}$ fresh herbs for Rosemary and Spearmint respectively at without pre-cooled samples. While it was increased from 1.29 to 1.65 and from 9.98 to 11.57 (g)/ $100 \mathrm{~g}$ fresh herbs by increasing storage temperatures from 2 to $6^{\circ} \mathrm{C}$.,for Rosemary and Spearmint respectively at with pre-cooled samples.
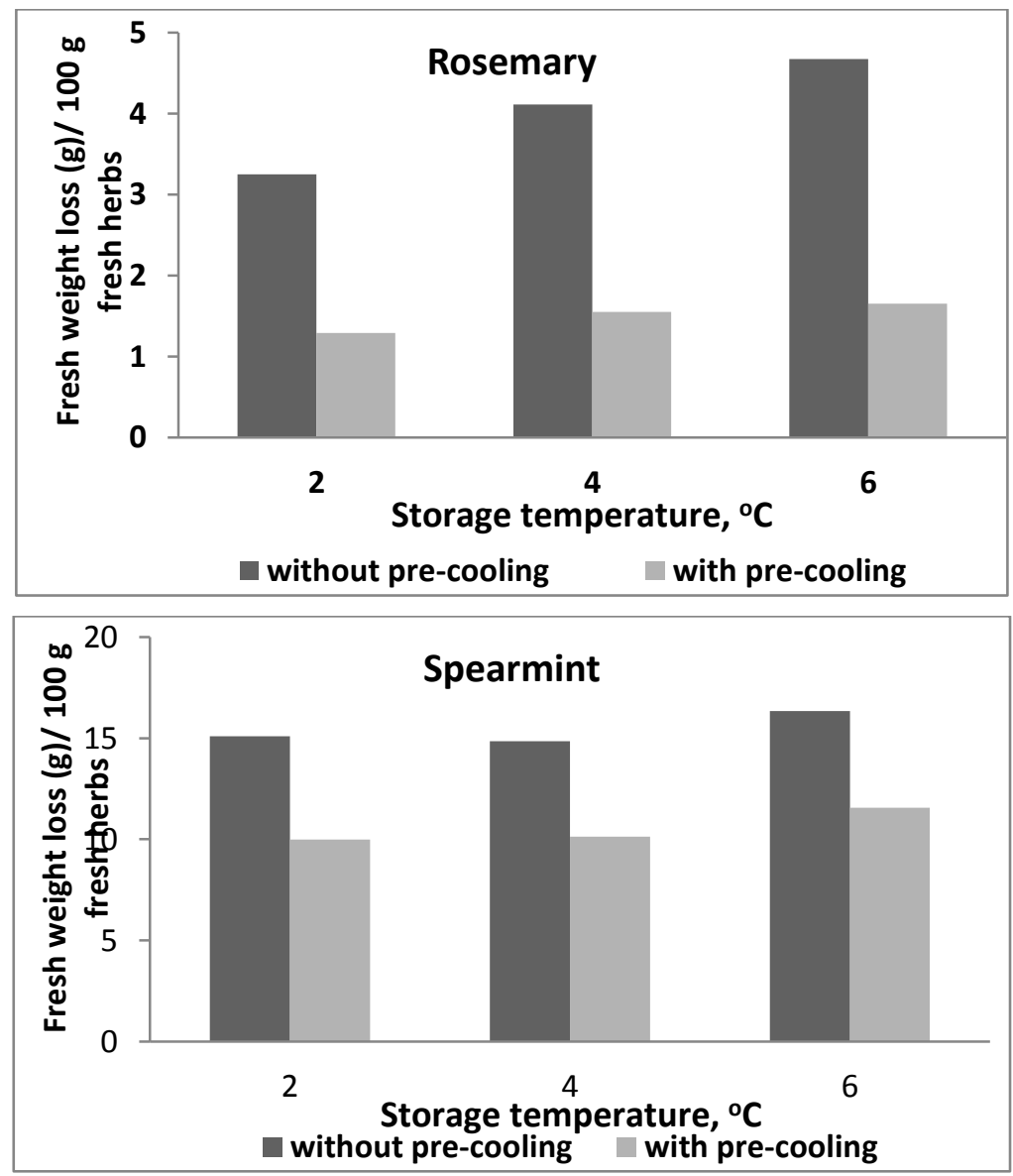

Fig.1: Effect of pre-cooling process and storage temperatures on fresh weight loss (g) of Rosemary and Spearmint. 
Chlorophyll (a and b) as affected by pre-cooling process and storage temperature.

Table (1) shows the effect of pre-cooling process and storage temperatures on chlorophyll a and b content of Rosemary and Spearmint. Data shown in Table (1) showed that there is no difference was found between pre-cooled and the non-pre-cooled samples and between the three storage temperatures of 2,4 , and $6{ }^{\circ} \mathrm{C}$ on chlorophyll ' $a$ ' an ' $b$ ' content for the plants under study.

These results may be return to, the herbs subjected to pre-cooling treatment prior to packing preserved greater amounts of chlorophyll with less colour change than those of non-treated herbs.

Table (1): Effect of pre-cooling and storage temperatures on chlorophyll (a and b) contents ( $\mathrm{mg} / \mathrm{g})$.

\begin{tabular}{|c|c|c|c|c|c|c|c|}
\hline \multirow{4}{*}{ Plants } & \multirow{4}{*}{$\begin{array}{c}\text { Chloro- } \\
\text { phyll, } \\
\text { (mg/g) }\end{array}$} & \multicolumn{6}{|c|}{ Treatments } \\
\hline & & \multirow{2}{*}{\multicolumn{3}{|c|}{$\begin{array}{c}\text { without pre-cooling } \\
\text { Storage temp., }{ }^{\circ} \mathrm{C}\end{array}$}} & \multirow{2}{*}{\multicolumn{3}{|c|}{$\begin{array}{l}\text { with pre-cooling } \\
\text { Storage temp., }{ }^{\circ} \mathrm{C}\end{array}$}} \\
\hline & & & & & & & \\
\hline & & 2 & 4 & 6 & 2 & 4 & 6 \\
\hline \multirow[t]{2}{*}{ Rosemary } & (a) & 0.33 & 0.33 & 0.32 & 0.33 & 0.33 & 0.32 \\
\hline & (b) & 0.22 & 0.22 & 0.21 & 0.22 & 0.22 & 0.21 \\
\hline \multirow{2}{*}{ Spearmint } & (a) & 0.59 & 0.59 & 0.59 & 0.61 & 0.61 & 0.60 \\
\hline & (b) & 0.35 & 0.35 & 0.34 & 0.35 & 0.35 & 0.34 \\
\hline
\end{tabular}

Effect pre-cooling process and storage temperatures on volatile oil (\%):

Data in Fig. (2) presents the influence of two different methods of precooling process and storage temperature on volatile oils percentage of Rosemary and Spearmint. It is also clear that from Fig. (2) there is high effect of pre-cooling process and storage temperatures on percentage of volatile oils. By using non-pre-cooling and decreasing storage temperature from 6,4 and $2{ }^{\circ} \mathrm{C}$, the percentage of volatile oils of Rosemary and Spearmint decreased in general. The percentage of distillate volatile oils from storage herbs decreased from 0.275 , to 0.201 $\%$ for rosemary by increasing storage temperatures from 2 to $6{ }^{\circ} \mathrm{C}$, respectively for Rosemary at non pre-cooled samples, while it was decreased from 0.229 to $0.198 \%$ for spearmint by increasing storage 
temperature from 2 to $6{ }^{\circ} \mathrm{C}$, respectively at non- pre-cooled samples. This means that, the volatile oil of the studied plants was affected by both pre-cooling and storage temperature.
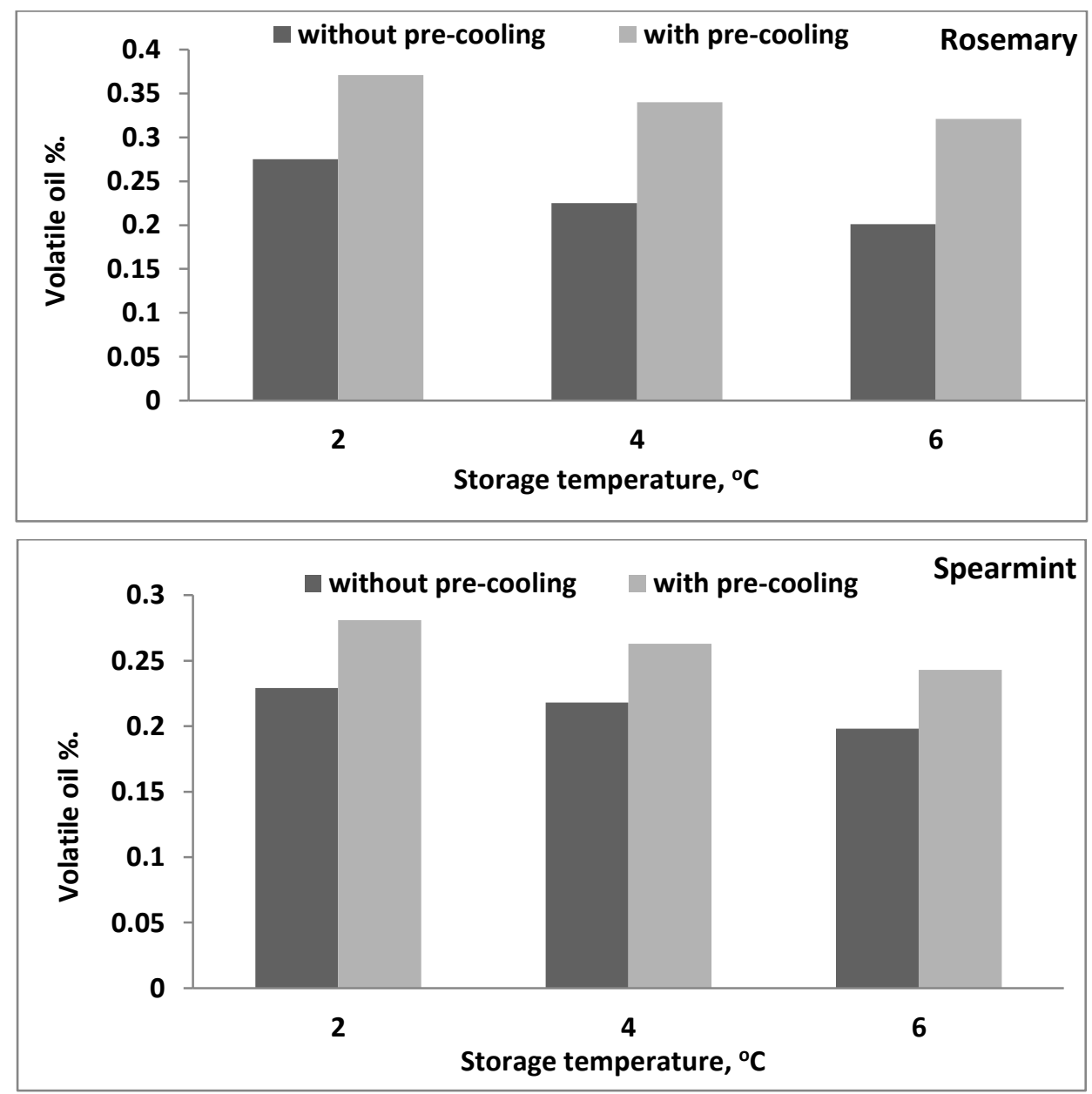

Fig.(2): Effect of pre-cooling and storage temp. on volatile oil percentage.

Effect of pre-cooling process on volatile oil components at storage temperature of $2^{\circ} \mathrm{C}$ for rosemary and Spearmint:

Data shown in Table (2) indicated that for rosemary herbs 14 component were identified, the main components was 1.8 cineole followed by linalool. Regarding, the effect of pre-cooling on volatile oil component, it could be concluded that, the 1.8 cineole content was $14.50 \%$ for the nonpre-cooled herb while it was $20.63 \%$ for the pre-cooled herb. 
Meanwhile, for the samples of Spearmint 11 components were identified; the main components were Carvone and limonene.

It could be seen that, the maximum Carvone was $60.99 \%$ obtained from the pre-cooled herb, while the minimum of $59.34 \%$ obtained from the non - pre-cooled herb. Also limonene was 16.17 and $16.65 \%$ for non pre-cooling and pre-cooled samples respectively.

Table (2): Effect of pre-cooling on volatile oil components (\%) at storage temperature of $2^{\circ} \mathrm{C}$.

\begin{tabular}{|c|c|c|}
\hline \multirow{2}{*}{ Components } & \multicolumn{2}{|c|}{ Rosemary (Rosmarinus officinalis L.) } \\
\hline & without pre-cooling & with pre-cooling \\
\hline $\mathrm{A}-$ pinene & 0.60 & 1.04 \\
\hline Camphene & 0.62 & 0.83 \\
\hline $\mathrm{B}$ - pinene & 0.91 & 0.91 \\
\hline Limonene & 3.51 & 6.63 \\
\hline$\Gamma$-terpinene & 8.31 & 10.60 \\
\hline 1.8 cineole & 14.50 & 20.63 \\
\hline Linalool & 18.52 & 23.64 \\
\hline Camphor & 7.14 & 6.86 \\
\hline P-cymene & 7.27 & 13.00 \\
\hline Bornyl acetate & 7.15 & 4.33 \\
\hline Borneol & 2.46 & 3.49 \\
\hline B-carophyllene & 0.93 & 0.71 \\
\hline Eugenol & 1.28 & 1.44 \\
\hline Unidentified & 7.28 & 9.55 \\
\hline \multirow{2}{*}{ Components } & \multicolumn{2}{|c|}{ Spearmint(Menthaviridis Linn.) } \\
\hline & without pre-cooling & with pre-cooling \\
\hline$\alpha$-pinene & 1.54 & 1.43 \\
\hline$\beta$-pinene & 3.94 & 4.01 \\
\hline Limonene & 16.17 & 16.65 \\
\hline 1,8 cineole & 0.74 & 1.02 \\
\hline$\gamma$-terpinene & 1.05 & 1.09 \\
\hline Linalool & 4.93 & 5.05 \\
\hline Carvone & 59.34 & 60.99 \\
\hline$\alpha$-terpineol & 2.29 & 2.41 \\
\hline B-carophyllene & 3.36 & 3.35 \\
\hline Eugenol & 3.24 & 1.61 \\
\hline Unidentified & 3.4 & 2.39 \\
\hline
\end{tabular}


Effect of pre-cooling and storage temperature on Safe storage period.

The effect of two different process (pre-cooling process and storage temperatures) on the storage period (days) of Rosemary and Spearmint are presented in Fig. 3. As shown in Fig.3, the storage period increased for the pre-cooled plants in comparison with non- pre-cooled samples. Also the storage period decreased by increasing the storage temperatures from 2 to $6^{\circ} \mathrm{C}$.

As shown in the figure, the highest storage period was 28 and 24 days for Rosemary and Spearmint, respectively which obtained for the pre-cooled herbs stored at $2^{\circ} \mathrm{C}$. While the minimum storage period of 9 and 10 days was obtained for the non- pre-cooled herb stored at $6{ }^{\circ} \mathrm{C}$. After these periods the herbs were rapidly deteriorating and their quality decreased within 48 hours at most.
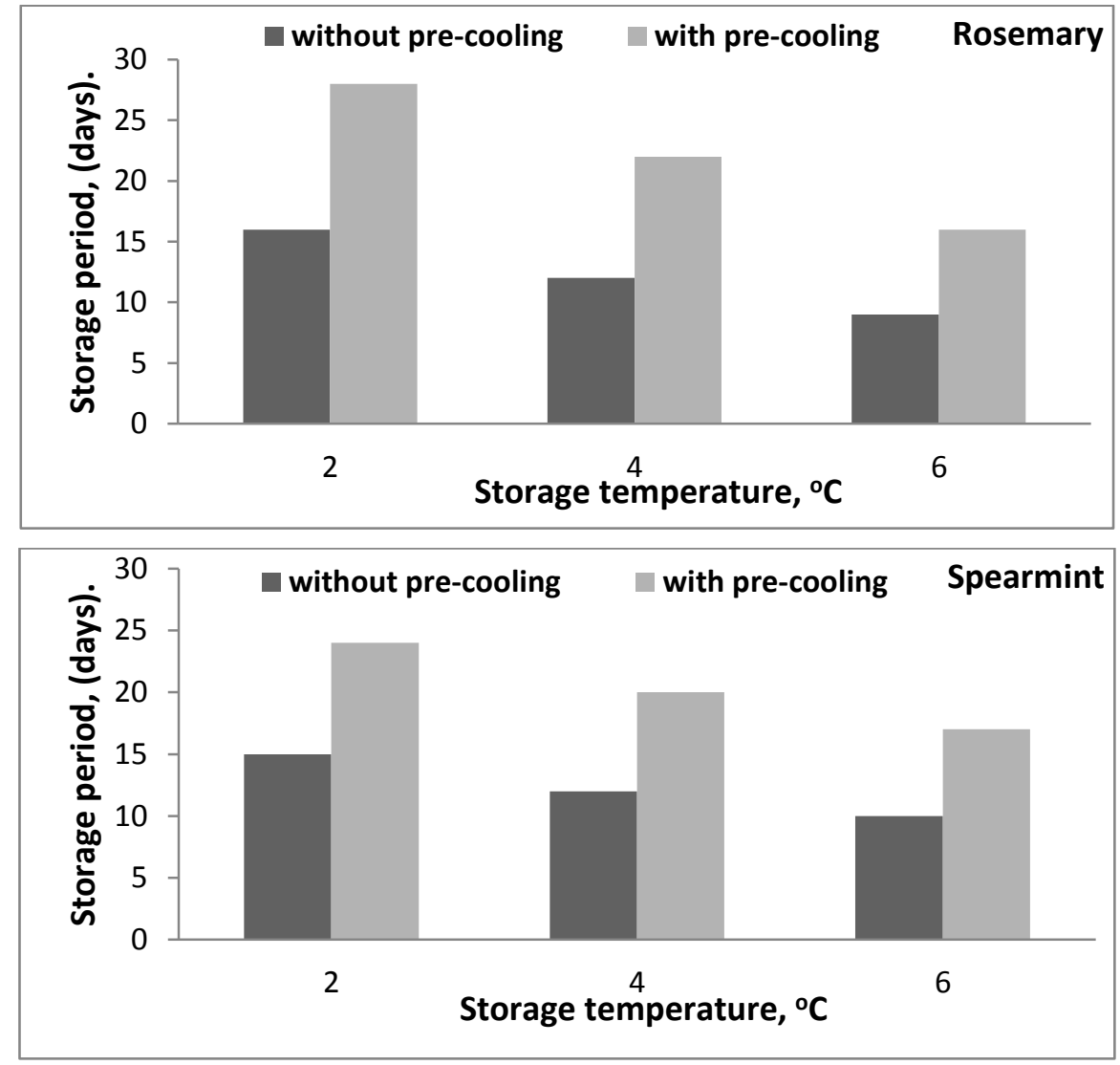

Fig. (3): Effect of pre-cooling and storage temperatures on the storage period (days). 


\section{CONCLUSIONS}

The obtained results could be summarized as follow:

1- For both herbs under study should be pre-cooled at $5{ }^{\circ} \mathrm{C}$ and stored at $2{ }^{\circ} \mathrm{C}$ and $98 \%(\mathrm{RH})$ to increase storage period, quantity and quality of oil, and decrease the fresh weight loss for fresh consumption or marketing. Storage period at these conditions were 28 and 24 days, fresh weight loss were 1.29 and $9.98(\mathrm{~g}) /$ $100 \mathrm{~g}$ fresh herbs, and percentage of the extracted volatile oil were 0.371 and $0.281 \%$ for Rosemary and spearmint herbs, respectively.

2- no difference found between pre-cooled and non-pre-cooled herbs and between the three storage temperatures of 2,4 , and $6{ }^{\circ} \mathrm{C}$ on chlorophyll 'a' an b content for all plants under study.

\section{REFERENCES}

Alvares, V. S. ; F. L. Finger; R. C. Santos; J. R. Negreiros; and V. W. D. Casali (2007).Effect of pre-cooling on the pot-harvest of parsley leaves. J. Food, Agric. And Environ. (JFAE), Helsinki, Finland, 5 (2): 31-34.

Ambasta SA. (1986). The useful plants of India, Publication and information directorate, CSIR, New Delhi. 1986; 365-367.

British Pharmcopoeia (1963).Determination of volatile oil in drugs. The Pharmaceutical Press, London.

CAGMC (Centre Authority for General Mobilization and Statistics (2002) "The annual stistical book for A.R.E.".

Cantwell, M. I. and M. S. Reid (1993).Post-harvest physiology and handling of fresh culinary herbs. J. Herbs, Spices, Med. PI., 1 :93127.

Gillies, S. L. and P. M. Tovionen (1995). Cooling method influences the post-harvest quality of broccoli. Hort. Sci., 30(2): 313-315.

Gomez, E.; J. Labarca; M. Guerroro; M. Marin and B. Bracho (1999).Post-harvest performance of coriander (Coriandrumsativum L.) under refrigeration.Revista de la 
Facultad de Agronomis, Univ. de Lzulia 16 (Suppl) 146-150 (Hort. Abst., 70 (4): 3514).

Kuen Woo, P; K. Homin and K. Chungho (2000). MA storage response of fresh lemongrass depending upon film source and storage temperature. Korean J. Hort. Sci. and Technol., 18(1):18-21.

Lawless, J. (1992).The encyclopaedia of essential oils. Element books Limited, Longmead, Shaftesbury, Dorset, London, USA, Element, Inc. 42 Broadway, Rockport, MA 01966. P. 164-165.

Mhaskar KS; E. Blatter and J.E. Caius (2000).Indian Medicinal Plant, Their Usage in Ayurveda and Unani Medicines, Sri Satyrur Publications, Delhi.2000; 8: 2726 - 2727.

Roura, S.I; L. A. Davidovich and C. E. Delvalle (2000). The influence of graduated nitrogen fertilizer application on yield and quality of sage(Salvia officinalis L.). Zeitchrift fur Arznei and Gewurzpflanzen., 1(3): 117-122.

Samarth, R. M. and A. Kumar (2003).Menthapiperita Linn. Leaf extract provides protection against radiation induced chromosomal damage in bone marrow of mice. Ind. J. Exp. Biol., 4: 229 237.1(3): 117-122.

Saric, M.; R. Kastrori; R. Couria; T. Cupina and I. Gerie (1967).Chlorophyll determination. Univ. Unovensadu Parkti kumis Fiziologize Bilijaka, Beagard, Hauncan, Anjiga, P. 215.

Vokovic-Gacis, B. and D. Simic( 1993). Identification of natural antimutagens with modulation effects on DNA repair. Basic Life Sci., 6: 269-274.

Watada, A. E.(1986). Effect of ethylene on the quality of fruits and vegetables. Food Technol., 405(5):82.

Yamauchi, N. and A. E. Watada (1991). Regulated chlorophyll degradation in spinach leaves during storage. J. Amer. Soc. Hort. Sci., 116: 58-62. 


\section{الملخص العربى}

\section{تأثيرالتبريد المبئى والتخزين المبرد على كمية وجودة بعض النباتات الطبية يسري بيومي عبد الحيث}

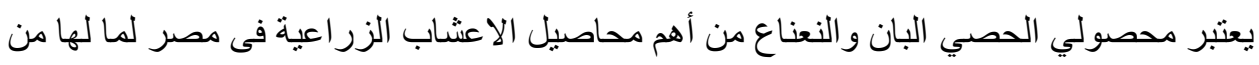

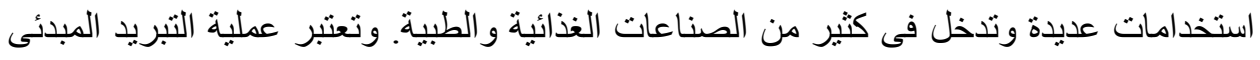

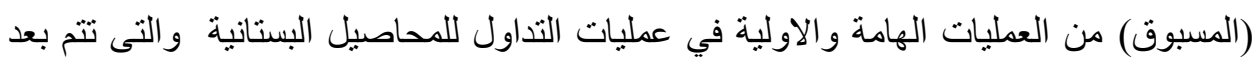

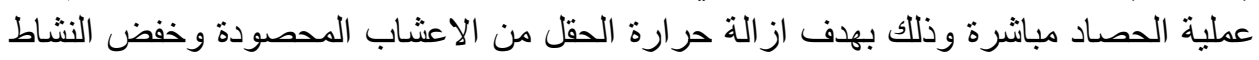

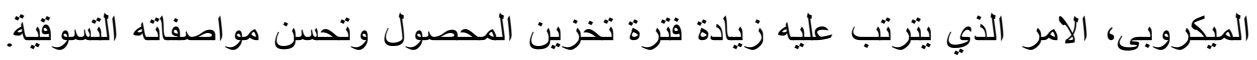

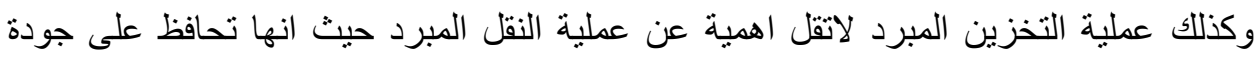

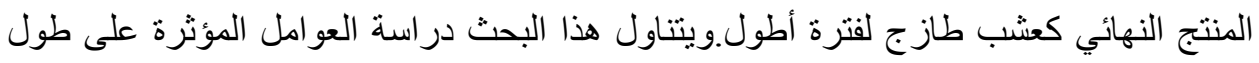

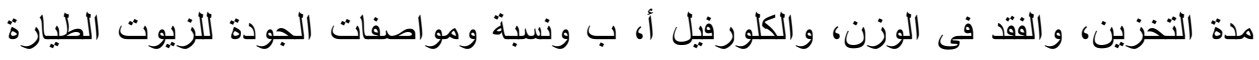

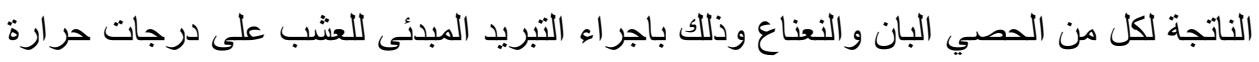

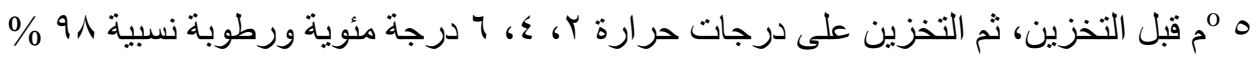

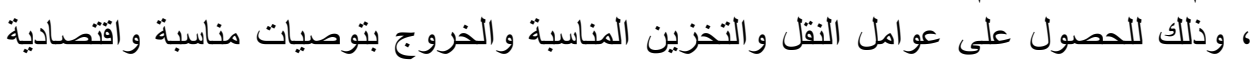

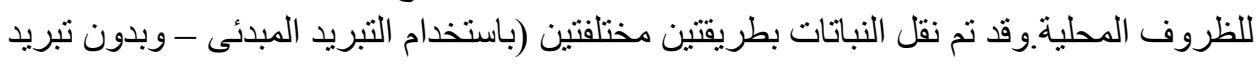

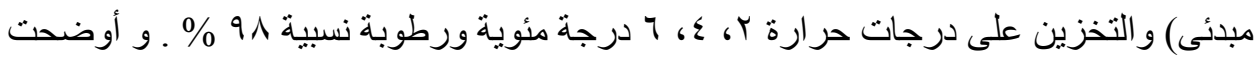

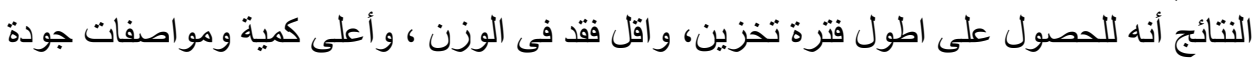

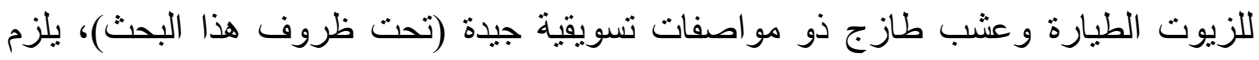

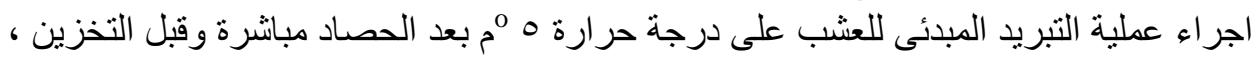

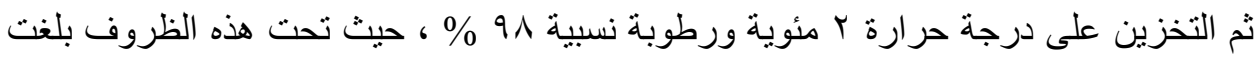

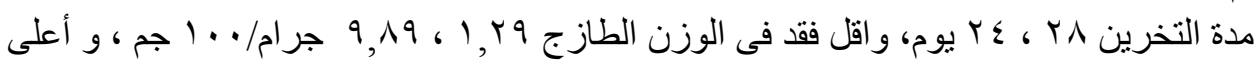

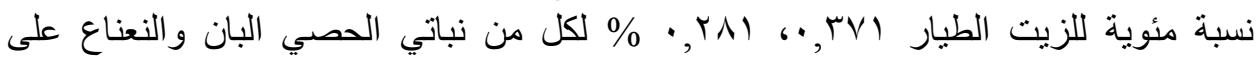

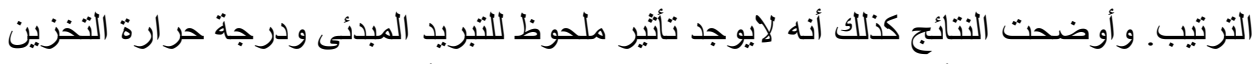
على محتوى الكلورفيل أ، ب (مجم/جر ام) لنباتي الحصي البان (أكليل الجبل) و النعناع. الكلمات الدالة: التبريد المبدئى ـ التخزين المبرد ـالحصي البان ـ النعناع - الزيوت الطيارة. 